\title{
LIMITES ÉTICOS JURÍDICOS DA BIOTECNOLOGIA NO SÉCULO XXI
}

Melissa Cabrini Morgato

Doutoranda em Ciências jurídicas políticas da Faculdade de Direito da Universidade de Lisboa -FDUL e Professora do Centro Universitário Eurípides de Marília - Univem. http://lattes.cnpq.br/4111588296514355

Edinilson Donisete Machado

Doutor em Direito pela Pontifícia Universidade Católica de São Paulo. Coordenador e Professor do curso de graduação em Direito e Coordenador dos Programas Lato Sensu em Direito do Centro Universitário Eurípides de Marília - Univem e professor titular da Universidade Estadual Norte do Paraná. http://lattes.cnpq. br/5801377676380146

\section{Resumo}

O presente trabalho tem por objetivo problematizar conseqüências éticas e jurídicas do desenvolvimento da ciência biotecnológica, principalmente no campo da engenharia genética. Dividimos as situaçóes apresentadas pela ciência biotecnológica entre as que podem ser ética e juridicamente justificadas: eugenia negativa, dado o potencial terapêutico de trazer benefícios aos seres humanos; e as que não são ética e juridicamente justificadas: eugenia positiva, visto que representam risco de danos para autocompreensão ética da espécie humana, assim como são incompatíveis com o imperativo de proteção à vida humana estruturado no Estado de Direito Iberoamericano. Concluímos que o respeito ao principio da dignidade humana deve se efetivar como uma diretriz máxima para o juízo moral de todos os homens, pois evitar práticas lesivas ao ser humano requer, além de normas legais e éticas, responsabilidade de ação para utilizar a tecnologia com fins exclusivamente terapêuticos e impedir que a sociedade de consumo e seus derivados artificializem completamente a natureza humana.

\section{Palavras-chave}

Bioética; Biodireito; Dignidade humana; Manipulação genética.

\section{Abstract}

The present paper discusses the ethical and legal consequences of developments in biotechnological science, with a focus on the field of genetic engineering. We classify 
situations originating from developments in biotechnological science depending on their ethical and legal justification, based on Habermas' reflections in his work "The future of human nature", and differentiate between negative eugenics, representing ethically and legally justified situations, given their therapeutic potential of bringing benefits to human beings; and positive eugenics, describing situations, which are not justified by Ethics and Law, since they represent risks for the ethical self-understanding of the human species and are also incompatible with the imperative nature of human life protection, which is structured by the Ibero-American constitutional states. We conclude that all moral judgments must follow the principle of human dignity as a major guideline, because the prevention of harmful practices against human beings requires, apart from legal and ethical rules, the responsibility to exclusively employ technologies for therapeutic purposes and to impede that the consumer society and its by-products completely artificialize the human nature.

\section{Key words}

Bioethics; Biolaw; Human Dignity; Genetic Manipulation.

\section{Introdução}

A problemática que se pretende avaliar está relacionada aos parâmetros jurídicos e éticos capazes de possibilitar que a ciência biotecnológica, principalmente no campo da engenharia genética, se desenvolva na busca de melhor qualidade de vida para o ser humano, sem desrespeitar os princípios presentes no campo da bioética e do direito. Entendemos ser necessário pensar nos valores que devem orientar a evolução científica, pois certamente também terão reflexos para as geraçóes futuras.

Apesar da bioética, por meio de seus princípios (autonomia, beneficência e justiça) delinear diretrizes éticas atinentes ao desempenho indiscriminado e ilimitado das práticas biotecnológicas que possam afetar o direito à vida e à dignidade humana, compete à ciência do direito, por meio dos direitos fundamentais historicamente consagrados pelas constituiçóes das democracias ocidentais, ordenar as situaçóes.

Inobstante isso, conforme será demostrado ao longo deste trabalho, na atual conjuntura política em que se desenvolve a biotecnologia, está se tornando cada vez mais remota a chance de se definir os limites da ciência e restringir as práticas biotecnológicas a terapia genética, ou seja a cura de doenças graves, incuráveis e incapacitantes, responsáveis por impor grave sofrimento ao homem.

Para tanto, entendeu-se importante avaliar o contexto contemporâneo em que a biotecnologia se desenvolve para em seguida separar as possibilidades apresentadas pela ciência biotecnológica entre as que podem ser ética e juridicamente justificadas (eugenia 
negativa), dado o potencial terapêutico de trazer benefícios aos seres humanos; e as que não são ética e juridicamente justificadas (eugenia positiva) visto que representam risco de danos à autocompreensão ética ${ }^{1}$ da espécie humana, considerada como fim em si mesma, assim como são incompatíveis com o cenário interno e internacional de proteção à vida humana estruturado nas constituiçôes dos modernos estados democráticos, cuja finalidade precípua é assegurar a vida digna.

Importa ressaltar que muitos dos argumentos utilizados neste texto com o objetivo de traçar um limite entre as práticas denominadas eugênicas positivas e negativas estão alicerçados na obra de Jürgen Habermas, o futuro da natureza humana: a caminho de uma eugenia liberal?.

\section{O Desenvolvimento da Ciência Biotecnológica}

Desde o final do século XVIII, em razão do desenvolvimento da ciência e da tecnologia, descobertas na área biomédica e genética tornaram mais cômoda e confortável a vida humana, porém delas advieram, paulatinamente, também novas preocupaçóes tanto éticas como jurídicas e políticas.

Com o impacto da genética na cultura contemporânea, o mundo começou a mudar de modo muito mais acelerado do que algumas décadas atrás. Mudança que exige uma reconfiguração de nossas perspectivas, concepçóes e certezas, no que diz respeito a aspectos fundamentais da natureza humana. A vida do gênero humano está deixando de ser a medida de todas as coisas, como foi o caso para boa parte de nossa tradição cultural, para ser também instrumentalizada, ou seja, acrescentada "ao enorme arsenal de coisas dadas do qual o homo faber seleciona livremente os meios de atingir seus fins" (ARENDT, 1993, p. 168).

A biotecnologia tem colocado o homem em face de situaçóes que trazem benefícios e prejuízos para sua vida. Por um lado, abrem-se as portas para cura de doenças, com base em intervençóes no material genético humano, mas, por outro, ameaça seus referenciais identitários e sua liberdade, com a possibilidade da clonagem humana ou intervençóes gênicas que permitem a seleção e a modificação de características, tais como a inteligência e a cor dos olhos.

Atualmente, as transformaçóes propiciadas pelo desenvolvimento da ciência e da tecnologia - sob a forma da razão instrumental - não se limitam a possibilitar a vida social, mas instauram um novo mundo, "no qual o ser humano, a natureza, a vida e a morte atravessam turbulências e experimentam mutaçóes” (SIBILIA, 2003, p. 15).

1 A autocompreensão ética da espécie, conforme avalia Habermas, na obra o Futuro da Natureza Humana, relaciona-se com a concepção que temos no plano infra-jurídico de seres vivos, livres, moralmente iguais e orientados por normas e fundamentos. 
O filosofo Peter Sloterdijk (2000, p. 46-47), na obra Regras para o parque humano, alerta para a aproximação de um período de decisão política quanto ao futuro do género humano, face os perigos de que uma "reforma genética das características da espécie" tenham consequências graves para o futuro da espécie humana.

Assim, o direito se vê instado a intervir em situaçóes inusitadas, em busca de soluçôes para problemas novos e graves, propondo limites e regras às pesquisas científicas.

A necessidade de regulamentar as situaçóes decorrentes dos progressos da biotecnologia exige uma reflexão a respeito do atual contexto político do desenvolvimento biotecnológico, bem como sobre as chances de compatibilização entre a dinâmica do progresso tecnológico e as exigências de respeitar valores éticos.

Neste contexto político e social, as figuras tradicionais do sujeito, do indivíduo, da pessoa foram absorvidas pela função social de produtor e consumidor, sendo cada vez mais definidas em função de seu relacionamento com o mercado. A sociedade dos homens passa a ser caracterizada como a sociedade das coisas, na qual é crescente o processo de reificação, em que o próprio homem tende a ser tratado como objeto de consumo (MARTINS, 2011, p. 18; SIBILIA, 2003, p. 48).

Para refletir a respeito das implicaçôes éticas, políticas e jurídicas do desenvolvimento da tecnociência, mais especificamente da biotecnologia, sobre os riscos de que a sociedade humana perca o controle e acabe por ser dominada pelo progresso técnico, de que o homem caminhe na direção de instrumentalizar a natureza e a vida dos outros homens, intentaremos contextualizar, a situação no interior da qual estão inseridas as normas, diretrizes éticas e legislativas sobre a utilização da pesquisa biotecnológica e os seus resultados no espaço Iberoamericano.

\section{A Biotecnologia no Início do Século XXI}

O século XXI nasceu marcado pelo desenvolvimento acelerado da sociedade de consumo, que se fez acompanhar por um crescente enfraquecimento das formas tradicionais de legitimação do poder estatal, gerando como consequência uma excessiva ampliação do espaço da vida privada.

Dando continuidade a um movimento histórico que hoje atinge proporçóes superlativas, a globalização se manifesta nos mais diferentes sectores da vida social, tais como o financeiro, o comercial, o cultural e o de comunicaçáo. Do ponto de vista econômico, esse processo ocasionou a internacionalização da produção e a supremacia do capital financeiro. $\mathrm{Na}$ esfera da comunicação, permitiu a eliminação das distâncias, a integração dos indivíduos e grupos em rede, com dimensão planetária, assim como a extensa massificação da cultura. As grandes empresas transnacionais impóem suas diretrizes aos Estados, 
constrangendo atributos fundamentais de sua antiga soberania, gerando uma crise das instituiçôes de controle e da ordem político-social (BECK, 1999, p. 14; HESPANHA, 2009, p. 428 e ss).

A globalização econômica está substituindo a política pelo mercado, dando ensejo a um modo de regulação social que gera formas inéditas de poder, autônomas e sem território, que debilitam a soberania nacional. Ademais, dificulta o esforço de legitimação de normas jurídicas e éticas que objetivam limitar as consequências indesejáveis do desenvolvimento biotecnológico e impedir que o Estado nacional sofra profundos abalos em seus poderes constituídos, pois sua identidade, soberania, e autoridade passaram a sofrer poderosa pressão das interferências de atores transnacionais.

O ordenamento jurídico positivo nacional e suas instituições são por demais limitados para regulamentar a pluralidade de situaçóes sociais, econômicas, políticas e culturais cada vez mais diversificadas, pois foram concebidos para atuar em marcos territoriais precisos. Seu alcance é cada vez mais reduzido, sua autoridade e poder começam a se esvair na mesma velocidade em que as barreiras geopolíticas vão sendo superadas (BARCHIFONTAINE, 2004, p. 43; GIDDENS, 2000, p. 28-29).

Disso se pode concluir que a economia global afeta a esfera jurídica, dificulta, ou até mesmo impossibilita a regulação e limitação da biotecnologia pelos estados-nação (HESPANHA, 2009, p. 453-455). Para ilustrar essa dificuldade, tomemos o seguinte exemplo: se um país decide proibir a clonagem, a engenharia genética na linha germinal humana, ou algum outro procedimento dessa natureza, as pessoas interessadas em utilizar essa tecnologia podem simplesmente se deslocar para outro país onde não há o mesmo impedimento legal (FUKUYAMA, 2002, p. 28).

Conforme avalia Erich Fromm, o mundo alienado do capitalismo leva o homem à perversão de todas as suas virtudes, sendo o único objetivo de sua vida a economia e o lucro. Num mundo capitalista e global, o desenvolvimento avassalador da biotecnologia assume enorme densidade e peso, aprofundando a alienação do homem da sua própria essência, o que "leva a um egoísmo existencial, descrito por Marx como a essência humana do homem convertendo-se em um meio para a existência individual dele. Ele o [trabalho alienado] aliena o homem de seu próprio corpo, natureza externa, vida mental e vida humana" (1970, p. 58).

Neste sentido, o conhecimento biotecnológico está colocado a serviço da economia global e sob o domínio da vida privada. Tudo tem um preço, tudo pode ser comprado. A vida tende a ser tratada como meio e as velhas instituiçóes disciplinares de direito e Estado têm extrema dificuldade de frear o processo e estabelecer a sensata medida do que é desejável e do que deve ser rejeitado. A vida é guiada pela sociedade de consumo, por escolhas e responsabilidades individuais, uma vez que as pessoas são orientadas por suas próprias preferências arbitrárias (FUKUYAMA, 2002, p. 106; SIBILIA, 2003, p. 172). 
No entanto, conforme avalia Fukuyama (2002, p. 106) um dos dados fundamentais do problema consiste precisamente na dificuldade de incorporação legal de tais "procedimentos equitativos", como definir tais procedimentos e processos, se os resultados das escolhas promovidas pelo próprio homem como por exemplo: no campo das armas nucleares, da industria bélica em geral, das máquinas informáticas sofisticadas e da biotecnologia, podem se converter em assustadora ameaça para ele próprio [?]. A biotecnologia, em especial, desperta temor pela lembrança ainda viva e dolorosa dos projetos eugênicos praticados em passado recente, pondo em risco a liberdade e a dignidade do homem.

Em nossos dias, o alcance e os limites de tais empreitadas tendem a ser cada vez mais determinados pelas diretrizes do mercado, que operam "conforme a lógica cega do capital, minguando a capacidade de ação dos organismos públicos, das instâncias políticas tradicionais e dos Estados-nação; instituiçóes que costumavam orquestrar o biopoder característico das sociedades industriais" (SIBILIA, 2003, p. 145).

É possível afirmar que houve uma ruptura no liame entre ética e técnica. O crescente utilitarismo contribui para isso, de forma que cada um espera que a tecnologia se desenvolva, para usá-la em seu benefício. Segundo Martinez e Mucherone, "nós ainda nos chocamos porque fomos criados a partir do liame clássico ética/técnica, mas o presentefuturo já prepara uma outra consciência, em que a ética surge como uma 'coisa estranha', e esse estranhamento ético não poderia ser mais grave" (2005, p. 3).

A insuficiência de um sistema de regulamentação e controle formal-governamental são fatos. Há interesses comerciais poderosos disputando mercado e tentando desatrelar as empresas de biotecnologia de limitaçóes éticas ou jurídicas efetivamente relevantes (SIBILIA, 2003, p. 145).

Nesse panorama, as geraçôes de direitos humanos historicamente configuradas enfrentam graves problemas para se implementar, pois seus valores embatem com os imperativos econômicos dos mercados, embate por meio do qual se sobressaem, o lucro, a produtividade e a competitividade.

Como já foi observado, capitalismo e a economia de atuação global arruínam os fundamentos do Estado e da economia nacional, o tecido social se torna poroso, a sociedade perde sua consciência coletiva, e, por consequência, "a busca por resposta para as grandes questóes do futuro não possui mais local ou sujeito"(BECK, 1999, p. 25).

Em face de um mundo globalizado e capitalista que vende biotecnologia, e que é capaz de programar a vida humana em laboratório para aliená-la, importa questionar: em que medida o atual sistema jurídico ainda se mantém capaz de regulamentar o desenvolvimento da ciência biotecnológica [?]. E com que meios poderia esse sistema evitar que a vida humana seja transformada em um produto a mais do mercado consumidor [?]. 
Náo se pode perder de vista que a edição de normas para evitar o uso nocivo da biotecnologia não é uma questão de fácil equacionamento, principalmente porque se situa em uma zona obscura, na qual o caminho para a prática eugênica é aberto também pelos interesses de grandes grupos transnacionais de pesquisa e por poderosos interesses econômicos industriais (SIBILIA, 2003, p. 153).

No interior do quadro que ora esboçamos, convém anotar as preocupaçóes de Manuel Hespanha, no que diz respeito ao enorme risco de instrumentalização da esfera jurídica em detrimento a satisfação dos interesses económicos. Preocupa-se, especialmente, com o fato de este direito gravemente afetado pela globalização ser "um direito cuja legitimidade democrática se perdeu, portanto; que se representa alguma vontade, não é seguramente a dos seus destinatários”. (2009, p. 444-455).

Numa visão realista, a promulgação de normas legais, apesar de importante fator, não pode ser considerada suficiente para controlar o desenvolvimento científico e resolver os problemas com que nos defrontamos.

A esse respeito compete-nos avaliar os argumentos de Jürgen Habermas:

No quadro de uma reflexão jurídico-política moralmente fundamentada, porém, a referência à força normativa do fáctico não faz mais do que alimentar o receio, por parte de uma opinião pública céptica, de que a dinâmica sistémica entre ciência, técnica e economia produza faits accomplis que não consigamos já controlar normativamente. A frouxa manobra da Fundação Alemã de Investigação Científica desacredita as declaraçôes tranquilizantes provindas de uma área de investigação que já é, em larga medida, financiada pelo mercado de capitais. Desde que a pesquisa biogenética se aliou aos interesses dos investidores e à pressão para o sucesso, fomentada pelos governos nacionais, o progresso biotecnológico desenvolve uma dinâmica que ameaça cilindrar os prolixos processos normativos de esclarecimento na esfera pública. (2004, p. 59).

Neste sentido, cabe aos profissionais, médicos e pesquisadores, conduzir sua ação com respeito à dignidade humana, de forma que os princípios da justiça, do respeito à autonomia e à beneficência sejam os imperativos morais de sua conduta.

Nesta linha de raciocínio, argumenta Daniel Serrão:

$\mathrm{O}$ antigo equilíbrio entre a cultura tecnológica, o poder político e os cidadãos está perdido, partiu-se. A globalização do poder económico, e a do poder político a ele ligado, suscitou, nos homens, uma contra resposta eficaz que é a da cidadania global, apoiada numa bioética global. (2008a, p. 379).

Assim, o respeito à dignidade da pessoa deve se efetivar como uma máxima para o juízo moral de todos os homens, pois evitar práticas lesivas ao ser humano requer responsabilidade 
de ação para impedir que a sociedade de consumo e seus derivados artificializem completamente a natureza humana. São as nossas decisóes coletivas, a serem tomadas nos próximos anos no que diz respeito a essa tecnologia, que determinarão a figura do futuro da humanidade (MUCHERONI; MARTINEZ, 2005, p. 5; SLOTERDIJK, 2000, p. 46).

Justamente por necessitarmos com urgência de reflexão e autorreflexão, há cabimento a preocupação de Habermas: "[...] impóe-se a questão de saber se a tecnicização da natureza humana altera a autocompreensão ética da espécie de tal modo que não possamos mais nos compreender como seres vivos eticamente livres e moralmente iguais, orientados por normas e fundamentos"(2004, p. 57).

Há grave risco de que a instrumentalização da vida humana, por meio de uma eugenia liberal, altere de modo irreversível essa autocompreensão ética da pessoa humana, considerada como fim em si mesma, podendo afetar as condiçóes necessárias para uma condução de vida autônoma, de reconhecimento recíproco e tratamento igualitário entre sujeitos morais e jurídicos (GIACÓIA JUNIOR, 2004, p. 5).

Que hoje em dia as relaçóes simétricas e igualitárias entre as pessoas estão ameaçadas de sofrer o enquadramento reificador e objetivante da produção (bio)técnica comprovase pelo predomínio do mercado de consumo sobre o curso das pesquisas genéticas, que também se utilizam do corpo humano como matéria-prima de aperfeiçoamento, ou seja, reduzem-no à categoria de objeto passível de manipulação e reconstrução, equiparando-o a uma máquina, a um corpo-máquina.

Assim, encontrar saída para o problema das consequências éticas indesejáveis do progresso tecnológico "dependerá, porém, de uma nova mentalidade política que não se perca no 'totalitarismo tecnológico', tão do gosto das corporaçôes e das naçóes que hoje são os privilegiados donos das máquinas e os senhores da tecnologia” (REALE, 1997, p. 44).

Após elucidar o cenário em que se insere a biotecnologia neste século, procuraremos avaliar sua aplicação prática para traçar um limite ético-jurídico no quadro institucional do moderno Estado de direito, especialmente porque há técnicas benéficas e importantes para salvaguardar a saúde e bem estar da humanidade e em contrapartida aquelas que colocam em risco a dignidade humana, face ao potencial de tornar a vida objeto de escolhas individuais e arbitrárias.

\section{A Eugenia Negativa $x$ Eugenia Positiva}

A eugenia, na história da humanidade, conduziu a práticas arbitrárias, discriminatórias e cruéis, destinadas a direcionar características hereditárias, eliminar doenças ou malformaçóes, com o objetivo de selecionar os indivíduos considerados mais fortes, saudáveis e inteligentes e melhorar os atributos da espécie humana (MELO, 2008, p. 19-20; PICHOT, 1997, p. 15 e ss). 
A palavra eugenismo teve várias acepçóes ao longo da história da humanidade, todavia desde sempre, o intuito era controlar a transmissão de traços hereditários, garantindo as futuras geraçóes melhor qualidade racial. A partir da obra de Melo (MELO, 2008, p. 20-84) teceremos, adiante, algumas consideraçóes a respeito do desenvolvimento histórico do eugenismo. $\mathrm{Na}$ antiguidade (período arcaico) as práticas eugênicas envolviam desde o infanticídio, caso o recém nascido não satisfizesse os padrôes de vigor físico instituído pelo Estado, até o favorecimento e controle da reprodução entre indivíduos considerados superiores.

Darwin, em 1871, em sua obra La Descendance de l'homme et la sélection sexuelle, sugere que a perpetuação de seres débeis deve ser nociva à raça humana e entende que "todos os que não podem evitar uma pobreza abjecta para os seus filhos deviam evitar casar-se, porque a pobreza é náo só um grande mal, mas tende a agravar-se, ao arrastar consigo a ociosidade para o casamento (Apud. PICHOT, 1997, p. 18).

Francis Galton, um dos pioneiros em definir o termo eugenia, relacionou-a inicialmente ao melhoramento das qualidades da raça humana. Em 1904 reformulou seu conceito para enfatizar "o estudo de fatores socialmente controláveis que podem elevar ou baixar as qualidades raciais das gerações futuras tanto física como mentalmente" (MELO, 2008, p. 25-26).

Consoante Black, Francis Galton era bem intencionado. Pensava em promover o melhoramento da espécie humana, por meio de casamentos melhores, favorecendo a eugenia positiva. Acredita que suas ideias foram interpretadas de forma negativa nos EUA e utilizadas para promover a eugenia negativa. Nos Estados Unidos entre 1907 e 1940, foram realizadas inúmeras castraçóes involuntárias em pessoas consideradas inaptas a reprodução. Avalia que o número de intervençôes cirúrgicas forçadas chegou a 14.568 . (BLACK, 2010).

No entanto, na Alemanha nazista o projeto eugênico iniciado pelos americanos atingiu seu ápice. $\mathrm{O}$ conceito de Eugenismo estava relacionado a higiene racial face a suposição de superioridade biológica da raça ariana. Importante anotar que as crises econômicas de 1923 e 1929 a 1933 contribuíram para reforçar os argumentos eugênicos, uma vez que os tratamentos das doenças hereditárias, mentais entre outras, sobrecarregava os custos do Estado. Inúmeras medidas foram adotadas para preservar a pureza da raça ariana e exterminar aquelas consideradas inferiores ${ }^{2}$ (negros, judeus, ciganos, homossexuais, Testemunhas de Jeová, criminosos). A classe médica atuou de forma intensa na execução dos programas Nazi de higiene racial (MELO, 2008, p. 72).

2 "Centenas de milhares de pessoas foram esterilizadas compulsoriamente e mais de seis milhóes perderam sus vidas em nome da higiene da raça, não somente na Alemanha, mas em todos os territórios ocupados durante a segunda guerra mundial" (DIWAN, 2007, p. 63-64) 
No período compreendido entre o final do séc. XI até 1945, surgiram em diversos países, tais como: Brasil, Portugal, Estados Unidos, Suécia, Dinamarca, Noruega e Finlândia, entre outros leis eugénicas destinadas a exterminar indivíduos "considerados racialmente inferiores ou indesejáveis" (MELO, 2008, p. 73).

A legislação eugénica se disseminou na Europa e em muitos outros países, de modo a distinguir entre os homens detentores de "bons" ou "maus" genes. Os primeiros, considerados saudáveis e superiores, logo pertencentes a boa raça, podiam livremente contrair matrimónio e procriar; os outros: doentes mentais, alcoólicos, criminosos, judeus, negros, entre outros, eram o "pesado fardo da humanidade", e, portanto eram submetidos a restrições quanto a reprodução ou até mesmo eliminados.

Muitas das medidas eugénicas adotadas nos Estados Unidos e Alemanha foram acolhidas por Portugal e Espanha. A legislação incorporou especialmente medidas de esterilização eugênica e certificados pré-nupciais (DUALDE BELTRÁN, 2004). A constituição brasileira de 1934 previa a implantação de exames pré-nupciais e educação eugênica nas escolas públicas (SOUZA, 2012).

Convém anotar que a eugenia engloba dois aspectos relevantes. O primeiro pode ser conceituado como eugenia positiva, ou seja, aquela que visa modificar as funçôes somáticas e mentais do ser humano, como a memória e a inteligência, bem como determinar características físicas, como a cor dos olhos e dos cabelos.

A eugenia negativa é aquela preocupada em diagnosticar, prevenir e curar enfermidades e malformação de origem genética, assim como proporcionar melhores condições de vida ao ser humano privado, de alguma forma, de certas funçóes vitais.

De acordo com Schramm (1997, p. 203):

Eugenia é um termo genérico do século XIX, que indica a ciência que estuda as condiçôes mais propícias à reproduçáo e melhoramento da espécie humana; eugenética representa a forma contemporânea da eugenia, uma tecnociência nascida nos anos 70, do encontro entre genética, biologia molecular e engenharia genética; eugenismo indica a forma ideológica e 'utópica' da eugenética, quer dizer, a convicção de que é possível substituir os genes 'ruins' pelos genes 'bons' e criar uma nova espécie de humanidade libertada de seu mal-estar e sofrimento.

Para Luiz Archer eugenia "é o conjunto de técnicas que favorecem a propagação de genes considerados benéficos [eugenia positiva] ou que desfavorecem a propagação de genes considerados maléficos [eugenia negativa]" (1995, p. 74).

Atualmente, a palavra eugenia ressurge com relevância em face das possibilidades advindas da biotecnologia, pois abrem o horizonte para a seleção dos genes capazes de melhorar a raça humana, evitar a transmissão de doenças hereditárias, selecionar os embriōes 
considerados "aptos", entre outras práticas, principalmente voltadas ao desejo dos pais de terem filhos saudáveis, belos, enfim bem qualificados geneticamente.

Habermas, na obra o futuro da natureza humana (2004, p. 24-25), preocupa-se com a necessidade e, na mesma medida, com a dificuldade de se separar a eugenia negativa, (considerada justificada), da positiva (vista de início como injustificada), face a fronteira fluída entre as intervençóes de caráter terapêutico e as destinadas a promover tão só o aperfeiçoamento genético.

Embora não seja possível traçar limites definidos e intransponíveis entre o uso lícito e o uso ilícito ou abusivo, considerado não terapêutico da ciência biotecnológica, é necessário criar mecanismos para evitar que o homem, tome as rédeas da evolução em suas próprias mãos e utilize a técnica segundo seu próprio arbítrio, uma vez que, conforme avalia Siqueira (1998, p. 15):

A história dos conhecimentos científicos comprova que a tecnologia, às vezes, coloca em marcha intervençóes que ganham dinamismo próprio, superando o horizonte inicial do pesquisador, o que nos ensina que, com frequência, somos livres para dar o primeiro passo, o segundo e os sucessivos nos convertem em escravos.

Importa destacar, após os julgamentos dos crimes praticados contra a humanidade sob o domínio do regime nazista, bem como face ao vazio ético que dominava as pesquisas científicas no séc. XX, inúmeros documentos internacionais foram redigidos contendo diretrizes éticas e morais com o intuito de orientar a ação dos pesquisadores e proteger a dignidade humana. Inobstante isso, o desenvolvimento cientifico no âmbito da engenharia genética, tal qual foi apresentado na primeira parte deste trabalho, ainda descortina grande peso e desafio à humanidade, pois se apresenta esperanças de melhorar a qualidade de vida, na mesma proporção nos expóe a dilemas éticos, relacionados ao uso irresponsável, contrário a dignidade humana.

Neste contexto, sem dúvida há necessidade de assegurar a liberdade de pesquisa científica, todavia, compatibilizando-a com outros valores consagrados historicamente nas constituiçóes dos modernos Estados de Direito. Essa reflexáo, ao nosso ver, passa obrigatoriamente pela definição do que se entende por eugenia positiva, ou seja, intervenção genética capaz de poupar ser humano de sofrimentos e doenças incuráveis, separando-a da eugenia negativa, a qual deve ser proscrita, pois nociva ao futuro da natureza humana.

\subsection{Eugenia Positiva: Uma Afronta a Dignidade Humana}

A eugenia positiva é a técnica que tem por objeto a manipulação do patrimônio genético do ser humano, de forma a torná-lo um meio para satisfazer interesses e preferências 
arbitrárias, por exemplo, atender interesses narcisistas de pais que desejam ter um filho com suas características genéticas, ou mesmo, outras características específicas, tais como olhos azuis, cabelos castanhos, estatura mediana e escolha do sexo.

Não há argumentos moralmente convincentes que justifiquem tais intervençóes, aqui denominadas, eugenia positiva, uma vez que não se trata de regenerar tecidos lesados, prevenir doenças ou malformaçóes de origem genética e que constituem sérias limitações à qualidade de vida de seus portadores, mas tão somente de atender preferências individuais daqueles que arbitrariamente desejam manipular as características de outrem. ${ }^{3}$

Esse caminho, ao contrário das práticas que pretendem melhorar as condiçóes de vida para a espécie humana, aponta para um novo conflito no curso ético reconhecido pela humanidade e abala profundamente os fundamentos da deontologia, que embasam os códigos jurídicos reguladores da conduta humana, sobretudo da tutela dos direitos da personalidade, solidificados nos modernos estados democráticos de direito.

Conforme avalia Habermas, as práticas eugénicas despertam preocupação acerca da identidade da espécie, pois, afetam a forma como nos autocompreendemos como membro dessa mesma espécie e consequentemente o modo como se alicerçam as nossas concepçóes de Direito e Moral (2004, p. 33).

A clonagem humana é uma prática eugênica positiva e tem por objeto a manipulação do patrimônio genético do ser humano de forma a alterar sua condição natural de ser livre e autônomo, portanto incompatível com o cenário de proteção à vida e à dignidade humana perquirido pela bioética e estruturado na legislação dos Estados Democráticos de Direitos ${ }^{4}$.

Essa técnica era considerada impossível até o momento em que cientistas do Instituto Roslin de Edimburgo, na Escócia, financiados por grande empresa de produtos farmacêuticos, obtiveram êxito na clonagem de um animal mamífero. Posteriormente, vários países, clonaram animais.

Entre as práticas eugênicas positivas é a clonagem a que mais assusta as pessoas no mundo todo, pois é uma reprodução assexual e agâmica, unicamente destinada a produzir seres biologicamente idênticos ao indivíduo que fornece o material genético. Em síntese, é a técnica por meio da qual se pretende fazer uma réplica idêntica de um ser humano.

3 Em Portugal, por exemplo, a lei 32/2006 de 26 de julho, artigo 7º, nº2, proíbe a utilização de técnicas que objetivem conseguir melhorar características não médicas do nascituro, designadamente a escolha do sexo. No mesmo sentido é a legislação Espanhola de Reproduçáo Assistida nº14/2006, bem como a disciplina do artigo 14 da Convençáo de Oviedo.

4 O protocolo anexo a convenção de Oviedo pró́be expressamente a clonagem humana em seu artigo $1^{\circ}$. Em Portugal a lei $n^{\circ} 32 / 2006$ de 26 de julho, artigo $7^{\circ}$, nº 1 , proíbe a clonagem reprodutiva. No mesmo sentido é a lei espanhola, que inclusive criminaliza a prática no país 
Conforme avalia Habermas: "o problema não é a semelhança das partes provenientes de uma mesma célula, mas sim a usurpação e a subjugação. Com essa técnica institui-se justamente uma instância decisória” (2001, p. 210)

Qualquer técnica intencionada a manipular a vida do ser humano de forma a colocá -lo à disposição de outrem é inadmissível, por ser incompatível com o cenário de proteção aos direitos do homem estruturado na Declaração Universal dos Direitos Humanos, entre outros documentos internacionais ${ }^{5}$, bem nas constituiçôes democráticas intencionadas a consolidar Estados democráticos livres, justos, igualitários e solidários.

Importa, ainda, observar: a clonagem humana, além de ser um dano aos princípios constitucionais que orientam o Estado Democrático de Direito, é, do mesmo modo, eticamente nociva ao ser humano, tanto no que tange à segurança do experimento, quanto no que diz respeito à autocompreensão, individualidade, originalidade personalíssima, autonomia, responsabilidade e liberdade do ser clonado.

Para Daniel Serrão:

o que caracteriza, define, singulariza e dá importância biológica e particular dignidade ética ao embrião gamético é que este não copia nem reproduz nenhuma identidade genética já existente. E que esta singularidade do seu comportamento só nele acontece porque ela é consequência de uma relação corporal de homem e mulher que tem, em si própria, uma significativa dignidade biológica e, em muitos casos, também humana, ética, jurídica e até religiosa. (2008b, p. 364).

Assim, a questão de uma possível experiência envolvendo a clonagem humana requer, além de análise dos pressupostos jurídicos de proteção à vida do ser humano, também ponderação ética relativa ao respeito ao ser humano e às consequências morais e sociais para o ser clonado.

Nesse âmbito, vale analisar os argumentos de Habermas, ao ponderar que a liberdade e autonomia da pessoa clonada é subtraída quando seu programa genético, que sempre foi obra do acaso, é decidido por outrem. Assevera o autor que o clone não é apenas a cópia de outrem, assim como são os gêmeos univitelinos, mas um ser cujo patrimônio genético é fruto de uma decisão arbitrária, sendo que essa decisão importa em "usurpação" e "subjugação" (2001, p. 210).

5 Os documentos de alcance internacional que visam proteger os direitos da pessoa humana e dignidade humana, tais como a Declaração Universal dos Direitos do homem, Convenção Europeia dos Direitos do Homem e das Liberdades Fundamentais, a Convenção sobre os Direitos do Homem e da Biomedicina e a Carta dos Direitos Fundamentais da União Europeia, vedam senão expressa, tacitamente, dado o conjunto de valores que asseguram a dignidade, autonomia e autodeterminaçáo ética a pessoa humana, praticas eugênicas positivas, em especial a clonagem humana. 
O fato de alguém estabelecer o patrimônio genético do outro ser institui uma instância decisória que sugere equiparação à situação da escravidão. Relação em que não há liberdade individual, uma pessoa é disposta como propriedade da outra. Escreve Habermas: "O proprietário do escravo rouba, de resto, a sua própria liberdade na medida em que priva a liberdade de uma outra pessoa" (ibid 2001, p. 211).

Desse modo, os avanços da genética no âmbito do que chamamos de eugenia positiva criará uma situação até agora desconhecida para os seres humanos, na medida em que o patrimônio genético, que sempre foi compreendido como um dado contingente, resultado de um processo guiado pelo acaso, será produto da escolha do outro (ibid 2001).

O fato de uma pessoa dispor do patrimônio, ou melhor, do destino genético de outra, logo de interferir na sua liberdade, implica na subtração do pressuposto para a ação responsável daquela. No caso do clone, este poderá atribuir ao outro os dados de seu destino e as consequências de suas açôes, que não mais constituem circunstância fortuita.

Assim, a partir do momento que ao clone é imposta uma sentença irrevogável de vida, resultado da decisão de outrem, sua autocompreensão ética poderá ficar distorcida, na medida em que não fará parte da mesma comunidade que os seres morais, concebidos de forma natural, integram. Terá de construir sua história a partir de condições genéticas impostas, não como o único autor de sua própria vida. (HOGEMANN, 2003).

Não se trata tão somente da questão da clonagem, mas de como todo ser humano, fruto de um processo eugénico positivo, sempre com vistas a satisfazer preferências arbitrárias - de seus pais ou programadores -, se autocompreenderá em relação à sua origem. Ética e moralmente fará diferença ser produto de experiência genética, que altera as relaçôes recíprocas e simétricas que servem de base para a autocompreensão de todos os homens livres e iguais em um Estado Democrático de Direito [?].

A preocupação de Habermas, na obra futuro da natureza humana, está centrada no risco de que projetos eugénicos liberais suspendam, de modo irreversível, as condiçóes para um tratamento reciproco e igualitário entre as pessoas, até entáo consideradas fins em si mesmas, pois os pressupostos da autonomia foram racionalmente rompidos pela escolha arbitrária de outrem (2004).

Neste sentido, a partir do momento que um homem dispóe do patrimônio genético do outro, privando-o de sua identidade natural, age de modo a subtrair a simetria que coloca os indivíduos do Estado Democrático de Direito, livres, autônomos e iguais no mesmo plano existencial, por alterar a perspectiva habitual de nascimento e vida, afetando a autocompreensão ética da espécie, compartilhada por todos os seres morais (ibd 2004, p. 37).

Assim, a intervenção e modificação do código genético de outrem, de modo a estabelecer suas características físicas, altera algo que Habermas chama de "esfera de 
indisponibilidade", fora do alcance de outras pessoas; visto que, além de ser um dano à forma como o próprio ser se autocompreenderá ética e moralmente em relação à pessoa que lhe infligiu uma sentença de vida irreversível, antes do seu nascimento, é também subtrair as suas condições de ação responsável.

O ser "geneticamente manipulado" se encontrará em posição jurídica assimétrica em relaçáo aos outros indivíduos, situaçáo que o coloca em desvantagem, pois a simetria entre os homens é pressuposto fundamental da personalidade moral. Portanto, não há igualdade ética nem jurídica entre este e quem o determinou. A vida se desenvolve a partir de uma base que lhe foi imposta por decisão alheia, e não daquilo que lhe foi dado pela natureza, pelo acaso, objeto da combinaçáo e variação natural dos genes paternos, que torna os indivíduos únicos e irrepetíveis.

Do exposto, resta claro que a práticas eugénicas positivas, além de serem eticamente nocivas ao ser humano, afetam também os conceitos constitucionais de direitos humanos e dignidade, uma vez que, no âmbito da ordem jurídica democrática, "os cidadãos só podem usufruir a autonomia igualitária privada e pública caso todos se reconheçam reciprocamente como autônomos" o que náo ocorre quando a condiçáo necessária de equivalência entre as pessoas na esfera jurídica é violada (Id 2001, p. 211).

Cumpre observar a forma pela qual é assegurada a vida humana. Desde o nascimento, compreende o modo como os seres se identificam no cenário atual dos direitos constitucionais, enquanto membros da mesma comunidade moral, tendo em vista as condiçóes essenciais para a nossa autocompreensão como seres livres e iguais. Uma vez rompida essa reciprocidade, essa simetria, poderá haver dano para o indivíduo e para os pressupostos jurídicos do Estado Democrático de Direito.

Os argumentos morais e éticos, no que diz respeito aos danos à identidade pessoal, bem como os argumentos jurídicos, no que tange ao princípio da dignidade humana, são entraves para a manipulação genética com vista à eugenia positiva, pois "criar-se-á uma instância decisória sem precedentes; e, com ela, uma condiçâo necessária para a equiparação normativa de todas as pessoas jurídicas individuais será violada” (ibd 2001, p. 219).

Nesse sentido, é de se considerar a relevância da teoria filosófica kantiana por considerar que os seres humanos, providos de razão, não podem ser comparados a coisas, instrumentalizados. Ao contrário, os seres racionais são chamados de pessoas, porque sua natureza já os designa como fim (GIACÓIA JUNIOR, 2004).

Por tudo isso, ao se deparar com os novos horizontes da biotecnologia, o homem deve refletir a respeito do que é ética e juridicamente aceitável, sob pena de ser romper os pressupostos essenciais de uma vida digna alicerçada em pressupostos de igualdade, autonomia e liberdade. 


\subsection{Eugenia Negativa: Oportunidade de Melhorar a Qualidade da Vida Humana}

Tarefa difícil, no atual estado da técnica e de extraordinária relevância é definir as práticas que se enquadram no conceito de eugenia negativa, ou seja, terapia genética, com o auxílio da engenharia genética com potencial para eliminar, alterar ou trocar os genes responsáveis pelo aparecimento de patologias genéticas, responsáveis pelo nascimento de pessoas condenadas a sofrer.

Esse é o principal argumento para torná-la ética e juridicamente justificada, pois apesar dos riscos inerentes ao procedimento, relacionados a alteração do patrimônio genético da humanidade, poderá prevenir inúmeras doenças graves e incuráveis. (HABERMAS, 2004, p. 123) A dor, conforme avaliam Pessini e Barchifontaine "destrói a integridade do corpo e a dor e o sofrimento podem destruir a integridade global da pessoa." (2008, p. 553) Assim, erradicar doenças que impóem sofrimento e dor é um passo importante para proporcionar uma vida mais saudável e digna ao ser humano.

Entre as inúmeras técnicas que podem ser incluídas no rol da eugenia positiva, relevante avaliar, em primeiro lugar, a terapia genética em células germinais humanas. É a intervenção efetuada no zigoto ou nos gametas, que promove alterações definitivas na herança genética do indivíduo.

A viabilidade, de se eliminar genes defeituosos, responsáveis pela manifestação de enfermidades, poderá apresentar riscos de alterar a constituição do patrimônio genético da humanidade, entretanto, poupará o ser humano dos sofrimentos causados pela manifestação de doenças graves, até mesmo consideradas incuráveis, e malformaçóes físicas e psíquicas de origem genética.

Importante, avaliar que a terapia genética em células germinais humanas, ao contrário da eugenia positiva, poderá ser um grande passo para oferecer melhores condiçóes de vida as futuras geraçóes, outrossim, não rompe a reciprocidade, igualdade e autonomia entre os indivíduos, pois não visa ao determinismo genético de características físicas, mas a eliminação de genes responsáveis por doenças hereditárias graves, que causam intenso sofrimento ao ser humano, de modo que é possível se supor a antecipação do consentimento das futuras geraçóes.

Inobstante isso, face a incerteza quanto aos efeitos colaterais ao indivíduo, assim como as inúmeras implicaçóes éticas relacionadas a alteração do patrimônio genético da humanidade, a manipulação genética em células germinativas humanas têm sido proibida por todos os comitês de ética, em todos os países do mundo ${ }^{6}$.

6 No Brasil, por exemplo, a lei de Biossegurança, art. $6^{\circ}$, proíbe a engenharia genética em célula germinal humana, zigoto humano e embriấo humano. 
Já o diagnostico genético pré-implantação ${ }^{7}$, permite identificar os genes "indesejados", com o objetivo de implantar no útero materno apenas os embrióes livres de mutaçóes genéticas responsáveis por enfermidades graves, com risco de transferência à sua descendência. Essa técnica é importante para prevenir o abortamento terapêutico ${ }^{8}$, autorizado na maior parte dos países do mundo.

Há argumentos no sentido de que tanto o aborto eugênico como o diagnóstico genético pré-implantação, alterarão, ao longo dos anos, se efetuados de forma sistemática, a herança genética da humanidade, todavia trata-se de alteração que trará benefícios se pensarmos que evitará doenças hereditárias graves, responsáveis, face ao sofrimento inegável, por afetar a dignidade da própria pessoa (MELO, 2008, p. 192-93).

Para Rui Nunes (2006, p. 169)

A terapia genética em células germinais poderá ser eticamente aceitável quando se demonstrar inequivocamente a sua inocuidade. Isto é, quando se comprovar que a probabilidade de se introduzirem alteraçôes irreversíveis no património genético global está reduzida para níveis aceitáveis. Neste caso, não parecem existir motivos suficientemente sólidos para que se impeça o tratamento de doenças genéticas graves, associadas a grande sofrimento e morte precoce, que se manifestam ao longo de geraçôes como, por exemplo, a diabetes mellitus (grifos do autor).

No mesmo sentido argumenta Habermas (2004, p. 26):

O recurso ao diagnóstico genético pré-implantação deve ser considerado por si só como moralmente admissível ou juridicamente aceitável, se sua aplicação for limitada a poucos e bem definidos casos de doenças

7 Esse procedimento deve ser utilizado tấo somente por casais com risco para determinadas doenças genéticas graves, com o intuito de evitar que os genes "indesejados" se manifestem em seus filhos. Em Portugal é uma técnica permitida pela lei 32/2006 de 26 julho, artigo $28^{\circ}$ e $29^{\circ}$. No mesmo teor é a lei espanhola 14/2006, artigo 11. Esse diagnóstico, submete o embriáo que se encontra num inicial de desenvolvimento, cinco a oito células, a uma biópsia de precaução. Caso se confirme alguma doença, o embriāo nâo será reimplantado na mãe, que pode ser poupada de uma gravidez de risco ou interrupção da gravidez.

8 Em Portugal, por exemplo, a Lei no 16/2007, que alterou o artigo $142^{\circ}$ do Código Penal, permite a interrupção da gravidez quando há previsão de que o nascituro sofrerá de forma incurável, de grave doença ou malformação congénita ou se trate de fetos considerados inviáveis. Esse não é o posicionamento adotado pelo Brasil, que em 2012, em sede açáo de descumprimento de preceito fundamental (ADPF no54) admitiu ser lícita a interrupção da gravidez nos casos de fetos que não tem o cérebro ou parte vital dele (fetos anencéfalos), todavia ressalta que quaisquer abortos, cujo pedido tenha por fundamento a anormalidade do feto com vida intrauterina, todavia com deficiências físicas ou mentais é considerado eugênico (Ex. sexo dúbio, lábio leporino, síndrome de down, distrofia muscular, entre outras deformidades). No que diz respeito ao aborto de fetos anencéfalos o Ministro do STF, Gilmar Mendes ao emitir seu voto, salienta que dos 194 países que fazem parte das Naçóes Unidas, 94 permitem a interrupção de gravidez de fetos anencéfalos. 
hereditárias graves que não poderiam ser suportadas pela própria pessoa potencialmente em questão

Ainda, seguindo esse raciocínio, se pudéssemos consultar as pessoas se elas prefeririam nascer com doenças que causam dor, dependência e malformaçóes de origem genética, certamente as respostas seriam não. Portanto, é razoável considerar que esse recurso é moralmente lícito, e não deve ser reprimido sob o argumento de afronta à dignidade e à ausência de consentimento das futuras gerações, pois elas serão beneficiadas (NUNES, 2006, p. 199).

Por essas razóes, uma vez tornadas legais e habituais as práticas eugênicas positivas capazes de suprimir genes responsáveis por doenças graves e incapacitantes, podemos antecipar o risco e a responsabilidade a que estarão sujeitos os pais, cujos filhos sejam fruto do acaso e não da técnica, pelo sofrimento e ressentimento do próprio filho doente. (HABERMAS, 2004, p. 123).

Diferente da terapia em células germinais aquela realizada em células somáticas, não implica na alteração definitiva do genoma do paciente, visto que consiste no tratamento das células responsáveis por determinadas patologias, através da introdução no organismo doente de células sadias (chamadas células tronco). Assim, após a terapia, as células inaptas, por falhas na herança ou informação genética, a cumprir sua função própria, passarão a fazê-lo.

Portanto, a terapia somática afeta somente a pessoa que está sendo tratada. Exemplo dessa situação é utilização das "células tronco" existentes nos tecidos dos organismos de crianças e adultos, como medula óssea, sangue, fígado, além das encontradas no cordão umbilical e placenta.

Essas células tronco são utilizadas há muitos anos sem grandes questionamentos éticos. Gozam de maior legitimidade se comparadas à terapia em células germinais humanas, pois as alteraçóes não são transmitidas para as futuras geraçóes, e há possibilidade de se obter o consentimento livre e esclarecido, respeitando a autonomia e autodeterminação do paciente, tudo em conformidade aos princípios jurídicos e bioéticos (ARAÚJO, 1999, p. 69).

Outra questão concerne especificamente à pesquisa em células tronco embrionárias; células do embrião humano denominadas pluripotentes, pois são capazes de se diferenciar em qualquer tecido do corpo humano. Essas células são obtidas de embrióes humanos produzidos por fertilização in vitro e não utilizadas no respectivo procedimento 9 .

9 A Convenção de Oviedo prescreve em seu artigo 180: "no 1 Quando a pesquisa em embriōes in vitro é admitida por lei, está garantirá um proteção adequada ao embriāo. no 2 A criação de embriôes humanos com fins de investigação é proibida. Em Portugal, a lei 32/2006 permite, sob as condiçóes estabelecidas 
As legislaçóes da maioria dos países que permitem a pesquisa com embriôes humanos tem em comum:

1) que sejam utilizados apenas embriōes excedentes dos processos de fertilização in vitro;

2) proibição de que sejam criados embrióes para este fim;

3) haja consentimento expresso dos progenitores.

Há inúmeros argumentos contrários a utilização de embriôes humanos em pesquisa, tanto de grupos religiosos quanto de juristas, que consideram existir vida humana a partir da fecundação do óvulo pelo espermatozoide. Não há consenso ético acerca do estatuto do embrião, nem mesmo de quando se inicia a vida humana, todavia sabemos que há, em quase todos dos países do mundo, embrióes mantidos congelados em clínicas de fertilização, cujo destino, se não destinados a pesquisa ou implantados em útero materno, será o descarte.

Assim, considerando que há embrióes congelados; que não há dados científicos convincentes para decidir quando o embriáo pode ser considerado pessoa humana; e que as células tronco dele extraídas podem ser introduzidas em organismos adultos para desempenhar funçóes que outras células não podem executar (dada sua característica de se diferenciar em todos os tecidos do nosso organismo, diferentemente das células tronco provenientes de tecidos adultos que se diferenciam em apenas alguns tecidos), torna-se razoável liberar o emprego desse recurso.

Cumpre acrescentar que tal procedimento (consoante os prognósticos da ciência biotecnológica) permitirá a cura de enfermidades tais como o mal de Parkinson, a diabetes, o Alzheimer, bem como reparar lesóes dos ossos, das cartilagens, da medula espinhal, por exemplo, das vítimas de acidentes do trânsito ou do esporte, de forma a contribuir para a melhoria da qualidade de vida do homem (FAGOT-LARGEAULT, 2004, p. 234).

Não objetivamos com este trabalho esgotar o tema, todavia daquelas práticas biotecnológicas avaliadas e enquadradas, a nosso ver, no cenário eugênico negativo, observamos que a ciência poderá trazer inúmeros benefícios a vida humana, de modo que não há razóes para impedir seu avanço em respeito, também, a liberdade de pesquisa, outrossim,

no artigo 90, a utilização de embrióes para investigação científica. Dentre os países da pertencentes a Uniāo Europeia, doze Países (Grã-Bretanha, Bélgica, Suécia, Espanha, França, Portugal, Dinamarca, Estônia, Finlândia, Grécia, Hungria, Letônia, Países Baixos e República Checa) permitem expressamente a pesquisa com células tronco embrionárias provenientes de embrióes supranumerários das técnicas de fertilização in vitro. Cinco Países (Bélgica, Suécia, Grã Bretanha, Espanha, Finlândia e Portugal), permitem inclusive a clonagem terapêutica. Três Países (Áustria, Alemanha e a Irlanda) somente permitem a pesquisa com linhagens de células tronco importadas; A Bulgária, Chipre, Luxemburgo, Malta e a Romênia não disciplinaram a matéria e quatro países (Lituânia, Polônia, Eslováquia e Itália) proíbem expressamente as pesquisas com células tronco provenientes de embriōes humanos. 
o grande desafio será definir de forma transparente os limites de utilização a evitar ferir a dignidade humana, valor que confere legitimidade aos modernos Estados democráticos.

Nessa medida, toda e qualquer discussão sobre os limites éticos a serem obedecidos nas pesquisas genéticas, especificamente as relativas à intervenção sobre o patrimônio genético do ser humano, devem estar pautadas na dignidade humana, bem como nos princípios de justiça, liberdade, igualdade, autonomia, entre outros, base da ordem constitucional. (SARLET, 2011, p. 72).

Nesse sentido, a manipulação genética, com vista à possibilidade da clonagem humana e as terapias genéticas, que coloquem em risco a autodeterminação ética e o respeito à autonomia assegurada aos agentes morais no contexto de nosso Estado Democrático de Direito, devem se submeter à limitação da soberania constitucional, informada pelo princípio da dignidade humana.

Ao contrário disso, a terapia genética, que visa curar doenças e eliminar os genes responsáveis pela manifestação de doenças graves e incuráveis, não deve ser condenada sob o pretexto de mostrar-se um atentado à dignidade da vida e da pessoa.

Assim, o princípio da dignidade humana, apesar da dificuldade em se estabelecer uma definição precisa, é o valor ou sentimento que possibilita que nos identifiquemos com os outros homens e reconheçamo-nos como portadores da mesma dignidade. Portanto, deve ser o vetor responsável pelo limite ético a ser observado pela ciência, é o indicativo das possibilidades e dos limites de açáo dos homens, como forma de preservar a humanidade de ser tornar mero instrumento para atender interesses econômicos particulares ou arbitrários.

\section{Perspectivas para o Atual Estado da Biotecnologia}

No decorrer do trabalho, verificamos que o desenvolvimento da ciência biotecnológica pode trazer benefícios e esperanças para saúde e qualidade de vida do ser humano, porém também pode ser utilizado de forma a causar danos, desrespeitando a dignidade da pessoa e os direitos humanos.

O dever de respeito ao ser humano como um fim em si mesmo torna ilegítima toda intenção de utilizar a vida humana para satisfazer interesses e preferências individuais arbitrárias, principalmente devido ao fato de que poderá afetar de forma irreversível a autonomia da pessoa, condição para que haja reconhecimento recíproco e igualitário. Portanto, em face das situaçóes lesivas que a biotecnologia nos apresenta, importa questionar: há um impedimento efetivo para a instrumentalização da vida humana rumo a uma eugenia liberal [?]

Para refletir a respeito dessas questóes, cabe retomar, como vimos no primeiro capítulo, ao atual cenário de mundo global e capitalista em que se desenvolve a biotecnologia 
e, entre outros fatores, em que se dá o enfraquecimento da legitimidade do poder Estatal e o aumento exponencial do espaço de atuaçáo da vida privada. Num tal cenário, torna-se difícil a tarefa de traçar uma linha divisória entre a eugenia positiva e a negativa, direcionando a pesquisa para a terapia e impondo restriçóes ao melhoramento, determinismo ou “aperfeiçoamento” genético da espécie.

Ainda há de se considerar que está se tornando escasso o número de pesquisadores sem laços com o mercado e indústrias biotecnológicas, sendo certo que os órgãos estatais deixaram de ser a maior fonte financiadora de pesquisa, pois que se avoluma também o investimento privado disponível para subsidiar as novas tecnologias. Esses fatores dificultam ainda mais a regulamentação da biotecnologia pelo Estado (FUKUYAMA, 2002, p. 225).

Neste sentido, atualmente, a esfera de atuação jurídico-positiva do Estado é insuficiente e incapaz de impedir que a biotecnologia se desenvolva de acordo com as regras do poder privado e global do capital, guiadas pelo interesse do consumidor e do pesquisador. O conhecimento está sob o domínio do mercado de tal modo que a vida também passou a ser definida como mais uma mercadoria, um produto. Contudo, evitar a aplicação de atos reificantes, que instrumentalizam a vida humana, é uma opção que dependerá do juízo moral de cada um de nós.

Na opinião de Sibilia (2003, p. 180):

A nova tecnociência aliada ao mercado capitalista desconhece as antigas fronteiras políticas e jurídicas; pelo contrário, segue seus impulsos fáusticos apostando na ultrapassagem de todos os limites que costumavam constranger a espécie humana.

Há de se considerar, porém, mesmo que seja importante uma regulamentação pelo Estado, por meio de disposiçóes normativas, instituiçóes ou agências reguladoras, para conter o impulso fáustico que guia o desenvolvimento e a aplicaçáo da biotecnologia -que, como Fausto, parece desconhecer quaisquer limites- , as proteçóes estabelecidas no âmbito legal e jurisdicional não são mais suficientes para estabelecer um parâmetro seguro, dentro do qual as novas descobertas não atropelem irreversivelmente valores que balizam a identidade, a dignidade e os direitos fundamentais do homem (SARLET, 2011, p. 25).

A partir dessa perspectiva, torna-se hoje urgente e necessário refletir de forma consciente e séria a respeito dos danos que a biotecnologia poderá trazer para a humanidade, pois a deliberação sobre uso e aplicação da biotecnologia é feita pelo consumidor, não pela legislação. Para serem válidas e eficazes, as normas legais dependem da obtenção de consenso entre homens. Portanto, deve-se fazer apelo para a ação consciente no sentido de respeitar a si e ao outro como um ser autônomo, único, livre, igual e independente de todos os demais, respeitando-o como um fim em si mesmo. 
Dessa forma, avalia Habermas: “[...] A universalidade das normas morais, que assegura a todos um tratamento igual, não pode permanecer abstrata; ela precisa permanecer sensível para levar em consideração as situaçôes e os projetos individuais de vida de todos os indivíduos"(2004, p. 73).

Para tanto, devemos colocar ênfase na faculdade humana de julgar, que deve sempre levar em consideração, em seus juízos, também o ponto de vista do outro, próximo ou distante, com quem interagimos. Como já ensinava Kant, o juízo moral de cada um de nós deve se expressar do sentido de não praticar uma ação "senão de acordo com uma máxima que se saiba poder ser uma lei universal, quer dizer só de tal maneira que a vontade pela sua máxima se possa considerar a si mesma ao mesmo tempo como legisladora universal' (grifos do autor) (1997, p. 76).

Nesse sentido, toda ação cuja máxima não possa ser capaz de ser convertida numa lei universal se autonegará, ou será arbitrária, não tendo condições de se legitimar argumentativamente, mas apenas de se impor pela astúcia ou pela violência. Portanto, uma ação que instrumentaliza a vida humana, ou seja um prática eugênica positiva, não pode se tornar uma lei universal, pois o homem como um ser racional, capaz de se autodeterminar, é um fim em si mesmo e nunca uma coisa, um meio para outros fins.

Todos os indivíduos têm o direito natural e inalienável de ter a própria vida, e de ser respeitado na sua qualidade de pessoa. A principal forma de se assegurar esse direito é o respeito à autonomia da vontade humana para deliberar, isto é, escolher, com idêntico respeito à autonomia de outrem, uma vez que todos os seres racionais possuem um valor em si mesmos, e respeitá-los significa tratá-los como fim, pois nenhuma pessoa deve ser tratada e manipulada ao bel-prazer de outras.

Consoante Kant, no reino dos fins, tudo tem um preço ou uma dignidade. Quando uma coisa tem um preço, pode-se pôr em vez dela qualquer outra como equivalente; mas quando uma coisa está acima de todo o preço, e portanto não permite equivalente, entáo ela tem dignidade (1997, p. 77).

A vida humana não tem preço, não pode ser relativizada e colocada à disposição de escolhas e preferências arbitrárias, dado o seu íntimo valor, a dignidade. Portanto, para resguardar a humanidade da instrumentalização, por meio da ciência biotecnológica, é preciso também contar com que não se perca de vista, em nossos dias, que todos os seres racionais, autônoma e voluntariamente, renunciem a suas perspectivas meramente egoístas e individuais, em favor de uma perspectiva universal de respeito à dignidade da pessoa.

Assim, "a ideia da humanidade do homem nos obriga a adotar aquela perspectiva do nós, a partir da qual nos consideramos uns aos outros como membros de uma comunidade inclusiva, que não exclui ninguém”(HABERMAS, 2004, p. 78). 
Evitar uma prática eugênica de aperfeiçoamento que suprima a liberdade de um pelo exercício da do outro, prejudicando a liberdade ética e as relaçóes recíprocas e simétricas entre as pessoas, dependerá do reconhecimento social e político do elo fundamental de reciprocidade, reconhecimento e solidariedade, que se encontra ameaçado de ser irreversivelmente rompido, podendo representar um fator de perturbaçáo para a humanidade.

Consoante avalia Habermas:

Sem aquilo que move os sentimentos morais da obrigaçáo e da culpa, da censura e do perdáo, sem sentimento de libertação conferido pelo respeito moral, sem a sensaçáo gratificante proporcionada pelo apoio solidário e sem a opressão da falha moral, sem a 'amabilidade' que nos permite abordar situaçóes de conflito e contradição com o mínimo de civilidade, perceberíamos necessariamente - e é assim que ainda pensamos - o universo povoado pelos seres humanos como algo insuportável. A vida no vácuo moral, numa forma de vida que não conheceria nem mais um cinismo moral, não valeria a pena. Esse julgamento exprime simplesmente o 'impulso' de se preferir uma existência da dignidade humana à frieza de uma forma de vida insensível às consideraçóes morais (2004, p. 101).

O homem deve se dar conta de que não há reciprocidade, ou seja, igual respeito por cada um e responsabilidade solidária para com todos, que seja possível em um mundo em que o ato reificante de uma pessoa afeta as bases para a autocompreensáo ética das outras. Uma vez possível a clonagem humana ou as técnicas genéticas arbitrárias de aperfeiçoamento, as intenções alheias, geneticamente estabelecidas, se apropriarão irreversivelmente da história de vida das pessoas programadas.

Nesse contexto, a decisáo de utilizar a engenharia genética para o bem ou para o mal, dependerá também da faculdade de julgar, que é própria do ser humano, mas que se exerce em concreto como julgamento pessoal de cada um de nós - náo de modo atomizado e solipsista, mas no plano de nossas relaçóes solidárias, éticas e políticas, no espaço ampliado da esfera pública. É nesse espaço que cabe lucidamente reconhecer o contexto da nova realidade - em seus aspectos positivos e negativos - em que estamos inseridos, e se manifestar de forma autônoma, no sentido de recusar qualquer procedimento que degrade a vida humana à condição de mais um objeto à disposição do mercado consumidor.

\section{Conclusões}

Por fim, as face ao avanço da ciência biotecnológica e das técnicas aqui enquadradas como eugênicas positivas encontramo-nos muito próximos do risco de ingressar em um futuro pós-humano em que a essência estável do que somos por natureza será irreversivelmente alterada pelo rompimento da simetria e reciprocidade entre os homens. Talvez possa ser o Admirável mundo novo, de Aldous Huxley, no qual os homens, apesar 
de saudáveis e felizes, perderam a verdadeira qualidade de seres humanos. Já não mais amam, aspiram, sentem dor, fazem escolhas, ou lutam para alcançar algum objetivo, porque sua natureza foi radicalmente afetada e transformada.

Assim, a única forma de evitar que a vida humana seja mais um objeto a disposição do mercado consumidor está na preservação da autonomia do homem em rejeitar, ou seja tornar indisponível, por sua própria vontade e decisão, aquilo que foi tornado disponível pela ciência biotecnológica e que ameaça romper as relaçóes recíprocas e simétricas, - indispensáveis para a condução de vida autônoma e digna dos homens - essenciais até hoje para sua compreensão como sujeito moral.

\section{Referências}

ARAÚJO, F. A procriaçáo assistida e o problema da santidade da vida. Coimbra: Almedina, 1999.

ARCHER, L. O progresso da ciência e o espírito. Cadernos de bio-ética, v. 10, n. do Centro de Estudos de Bioética, p. 74, 1995.

ARENDT, H. A condiçáo humana. 6. ed. Rio de Janeiro: FOR UNIV, 1993.

BARCHIFONTAINE, C. DE P. DE. Bioética e início da vida : alguns desafios. São Paulo, SP: Idéias \& Letras ; Centro Universitário São Camilo, 2004.

BECK, U. O que é globalização? : equívocos do globalismo respostas à globalização. Traducao André Carone. São Paulo: Paz e Terra, 1999.

BLACK, E. Edwin Black revolve as raízes americanas da eugenia nazista, 9 maio 2010. Disponível em: <http://holocausto-doc.blogspot.com.br/2010/05/edwin-black-eugenia-nazista-eua.html>. Acesso em: 7 ago. 2012.

DIWAN, P. Raça pura : uma história da eugenia no Brasil e no mundo. São Paulo, SP: Editora Contexto, 2007.

DUALDE BELTRÁN, F. La profilaxis de la enfermedad mental en la psiquiatría franquista: esquizofrenia, eugenesia y consejo matrimonial. Revista de la Asociación Espańola de Neuropsiquiatría, n. 92, p. 131-161, dez. 2004.

FAGOT-LARGEAULT, A. Embriōes, células-tronco e terapias celulares: questôes filosóficas e antropológicas. Estudos Avançados, v. 18, n. 51, p. 227-245, ago. 2004.

FROMM, E.; MARX, K. Conceito Marxista do homem. Rio de Janeiro: Zahar, 1970.

FUKUYAMA, F. Our posthuman future consequences of the biotechnological revolution. New York: Picador, 2002.

GIACÓIA JUNIOR, O. Sobre Técnica e Humanismo. Sobre técnica e humanismo, Cadernos IHU idéias. v. ano 2, n. 20, p. 27, 2004. 
GIDDENS, A. Mundo na era da globalização. Traducao Saul Barata. Lisboa: Presença, 2000

HABERMAS, J. A constelaçáo pós-nacional ensaios políticos. São Paulo: Littera Mundi, 2001.

HABERMAS, J. O futuro da natureza humana: a caminho de uma eugenia liberal?. Sáo Paulo: Martins Fontes, 2004.

HESPANHA, A. M. O caleidoscópio do direito : o direito e a justiça nos dias e no mundo de hoje. Coimbra: Almedina, 2009.

HOGEMANN, E. R. R. S. Conflitos bioéticos : o caso da clonagem humana. Rio de Janeiro: Editora Lumen Juris, 2003.

KANT, I. Fundamentaçáo da metafísica dos costumes. Traducao Paulo Quintela. Lisboa: Ediçóes 70, 1997.

MARTINS, H. Experimentum humanum : civilizacão tecnológica e condicão humana. Lisboa: Relógio d'Água, 2011.

MELO, H. P. DE. Manual de biodireito. Coimbra: Almedina, 2008.

MUCHERONI, M. L.; MARTINEZ, V. C. Estado - Ciência e Biossegurança. Revista de Derecho Informático: Alfa-Redi, Sociedad de la Información. v. 87, n. Octubre, 2005 .

NUNES, R. Arguição da dissertação de doutoramento em direito da mestre Helena Melo sobordinada ao tema Implicaçóes jurídicas do projecto do genoma humano: Constituirá a discriminação genética uma nova forma de Apartheid? Themis: revista de direito, v. ano VIII, nº12, p. 189-202, 2006.

PESSINI, L.; BARCHIFONTAINE, C. DE P. DE. Problemas atuais de bioética. 8ª ed. São Paulo: Edicóes Loyola, 2008.

PICHOT, A. O Eugenismo: genetistas apanhados pela filantropia. Lisboa: Instituto Piaget, 1997.

REALE, M. Questóes de direito público. São Paulo: Saraiva, 1997.

SARLET, I. W. Dignidade da pessoa humana e direitos fundamentais : na constituicao federal de 1988. $9^{\mathrm{a}}$. ed. Porto Alegre: Livrario do Advogado, 2011.

SCHRAMM, F. R. Eugenia, eugenetica e o espectro do eugenismo: consideracoes atuais sobre biotecnociencia e bioetica. Bioética, v. 5, n. 2, p. 203-220, 1997.

SERRÃO, D. Os desafios contemporâneos da genética. Estudos de direito da bioética, v. II, n. Almedina, p. 369-379, 2008a.

SERRÃO, D. O clone humano, perspectivas científica, ética e jurídica. Estudos de direito da bioética, v. II, n. Almedina, p. 345-368, 2008b. 
SIBILIA, P. O homem pós-orgânico corpo, subjetividade e tecnologias digitais. Rio de Janeiro: Relume Dumará, 2003.

SIQUEIRA, J. E. DE. Etica e tecnociencia: uma abordamem segundo o principio da responsabilidade de Hans Jonas. Londrina: Universidade Estadual de Londrina, 1998.

SLOTERDIJK, P. Regras para o parque humano uma resposta à carta de Heidegger sobre o humanismo. São Paulo, SP: Estação Liberdade, 2000.

SOUZA, V. S. DE. AS IDÉIAS EUGÊNICAS NO BRASIL: ciência, raça e projeto nacional no entre-guerras. Revista Eletrônica História em Reflexão, v. 6, n. 11, 2012. 